\title{
RACE, ETHNICITY, DISCRIMINATION AND VIOLENCE IN "COLOUR-BLIND" FRANCE
}

\section{Kamban Naidoo*}

\section{ABSTRACT}

The Universalist ideals of the French Revolution, which proclaimed that all men are born equal, inspired a principle that crystallised during the nineteenth-century Republican period. This principle asserts that racial and ethnic differences have to be minimised. Race and ethnicity are, therefore, theoretically not recognised in France. The only recognised distinction in France is between a French citizen and a foreigner. As a result of this principle, a vestige of the late nineteenth century, any laws, government policies, data and research that are based on race or ethnicity, are prohibited in France. There is consequently a paucity of comparative research and data on racial and ethnic groups in France. Adherence to this principle has also stymied honest debates about racism and racial discrimination in France. Since the twentieth century, however, there has been a tendency to depart from this principle, as evidenced by several government policies and practices that tacitly recognise race and ethnicity. A departure from the principle is also evident in several laws that make explicit reference to race and ethnicity. Such laws include anti-discrimination laws, laws that prohibit incitement to racial violence and laws that are akin to hatecrime laws in the Anglo-Saxon world. This contribution examines some of these laws and government policies, as well as the historical circumstances that led to their enactment and implementation. It focuses on migration to France from the

* Associate Professor, Department of Criminal and Procedural Law, University of South Africa. 
mid-twentieth century, and on the social and economic conditions of migrants. A departure from the Universalist principle, which espouses the non-recognition of race and ethnicity, was inevitable, since by the mid-twentieth century, France had become a racially and ethnically-diverse country, in which racial and ethnic discrimination and violence were widespread. In the conclusion, some consideration is given to the relevance of the principle that espouses the non-recognition of race and ethnicity, and which inspired the adoption of a "colour-blind" assimilationist model in present-day France.

Key words: France; race; ethnicity, Universalist principles; discrimination; violence

\section{Introduction}

Prior to the French Revolution, French citizenship was restricted to certain classes of men who enjoyed full political and economic rights. ${ }^{1}$ It is widely accepted that the French Revolution inspired the Universalist ideals of the equality of all men and a common French citizenship, which recognized no hierarchy or differentiation based on class, race or origin. ${ }^{2}$ These Universalist ideals may be traced to La Déclaration des Droits de l'Homme et du Citoyen de $1789,{ }^{3}$ which is regarded as a solemn declaration of the natural, inalienable and sacred rights of man. ${ }^{4}$ From the late eighteenth century onwards, a principle which dominated French government policies was the minimisation of racial and ethnic differences, ${ }^{5}$ in order to establish a united nation. ${ }^{6}$ The post-Revolution French Republican model was based on the notion of a nation-state which emphasised universalism, detribalisation, allegiance

1 Tilly 1995: 227.

2 Dubois 2000: 19; Schor 2001: 44; Tilly 1995: 228; and Brubaker 1990: 380.

3 La Déclaration des Droits de l'Homme et du Citoyen de 1789 available at http://www. egifrance. gouv.fr/Droit-français-Constitution/Déclaration-des-droits-de-l'homme (accessed 1 Apr 2019) and hereinafter referred to as the Declaration of the Rights of Man and of the Citizen of 1789. It should be noted that as a French second-language speaker, all French to English translations in this submission are the writer's own.

4 Article 1 of the Declaration of the Rights of Man and of the Citizen of 1789 proclaims that all men are born free and remain free and equal in law. However, Schor 2001: 47 and Brubaker 1990: 380, point out that women and slaves, who constituted a large segment of the French population, were left out of the 1789 Declaration. Slavery was abolished in French colonies in 1848. Women in France were permitted to vote in the mid-twentieth century.

5 The writer would like to note that the term "race" in this submission refers to the inherited physical and biological characteristics of human beings, which include skin colour, facial features and hair texture. These characteristics have often been used to deny rights and privileges to certain groups. While the term "ethnicity" may include common racial origins, it is a wider concept than race since it refers to shared historical origins, a common culture and language, and to shared religious values.

6 Body-Gendrot 2008: 93; Schor 2001: 58; and Barou 2014: 644. 
to the nation-state and the ideals of the Revolution. ${ }^{7}$ This model was based on a notion of citizenship that, theoretically, took no cognisance of race and ethnicity, since all humans were regarded as belonging to one race. ${ }^{8}$ According to the present French Constitution, the French Republic is a single and indivisible entity, where all citizens are equal before the law without distinction as to race, origin or religion. ${ }^{9}$ Racial and ethnic groups are not recognised in French law since such recognition could fragment the unity of the state. ${ }^{10}$

France has consequently been described as a "colour-blind" state where laws, government policies, research and statistics that are based on race and ethnicity are prohibited. ${ }^{11}$ A 1978 law prohibits the recording and storage of any data that may reflect the racial or ethnic origins of French citizens. ${ }^{12}$ The only officially recognised distinction is between a French citizen and a foreigner. ${ }^{13}$ A common French adage is therefore, Il n'y a que des citoyens. ${ }^{14}$

Notwithstanding the non-recognition of race and ethnicity in France, several French laws make explicit reference to race and ethnicity - an ostensible departure from the Universalist principle of the non-recognition thereof. ${ }^{15}$ The French Constitution, for example, originally referred to the principle of equality of all citizens before the law without distinction as to origin, race or religion. ${ }^{16}$ Reference to race and ethnicity also exists in a 1972 law against racism and in a 1990 law against racism, anti-Semitism and xenophobia. In 2003 and 2004, laws were passed that allow for the imposition of enhanced penalties on offenders convicted of specific crimes motivated, inter alia, by the race or ethnicity of the victim. ${ }^{17}$ Several

7 The post-Revolution French nation-state thus subjugated the languages and cultures of several ethnic minorities in France including Basque, Catalan, Breton, Corsican and Occitan. See Weil \& Crowley 1994: 112; and Safran 1984: 461.

8 Ndiaye 2005: 97; Dobbin 2001-2002: 835; Bonnet 2014: 1278; and Safran 1984: 447.

9 Article 1 of the French Constitution of 1958. As will become apparent in the conclusion of this contribution, this article of the French Constitution was amended in 2018.

10 Diémert 2005: 112.

11 Vourch, De Rudder-Paurd \& Tripier 1996: 146; Möschel 2011: 1656; Bleich 2000: 52; and Dobbin 2001-2002: 833.

12 La loi Informatique et Libertés no. 78-17 du 6 janvier 1978 prohibits the recording and storage of personal data that reflects race, religious affiliation, political beliefs, trade union membership and health status, unless it is with the express consent of the person concerned or in exceptional cases allowed by law. The provisions of this law have been codified in art 226-19 of the French Code Pénal, hereinafter referred to as the French Penal Code.

13 Bleich 2000: 52 and Vourch, De Rudder-Paurd \& Tripier 1996: 146. Consequently, policies that specifically protect ethnic-minority groups and provide for racial quotas, such as the policy of affirmative action, are rejected in France. See, further, Möschel 2011: 1656; and Costa-Lascoux 1994: 372 .

14 Which is translatable into English as "There are only citizens". See, further, Pager 2008: 380

15 Costa 1992: 342; and Bird 2000: 407.

16 Article 1 of the French Constitution of 1958 (see n 9) supra.

17 These laws, which allow for the imposition of enhanced penalties, may be regarded as the equivalents of hate-crime laws in France. Hate-crime laws specifically criminalise conduct motivated by prejudice towards personal victim characteristics, such as race and ethnicity. Once convicted, perpetrators of such conduct could be subjected to enhanced or aggravated penalties. See, further, the UK Crime and DisorderAct of 1998 (c. 37), which is a British hate-crime law. 
government policies and initiatives also take cognisance of race and ethnicity, albeit not explicitly. Such departure from the principle of the non-recognition of race and ethnicity was necessary in order to accommodate the problems of discrimination and racial and ethnic violence in a country that had become increasingly diverse from the mid-twentieth century. ${ }^{18}$ These laws and government policies, and the historical circumstances that led to their enactment and implementation, form the central focus of this submission. In this regard, particular emphasis has been placed on migration to France in the twentieth century and on the social and economic conditions of migrants. The relevance of the Universalist principles in twenty-first century France is considered in the conclusion. The submission commences, however, with a brief consideration of some of the negative consequences of the non-recognition of race and ethnicity in France.

\section{The negative consequences of the non-recognition of race and ethnicity in France}

While the French "colour-blind" approach is regarded as a strategy to counter racism, ${ }^{19}$ France's colour-blindness in relation to race and ethnicity has had several negative consequences. Black Africans ${ }^{20}$ in particular, have become invisible as a social group in France. ${ }^{21}$ The limited available data about ethnic and minority groups in France has had a negative effect on comparative studies focusing on ethnic and racial groups. ${ }^{22}$

Moreover, many French social scientists, writers and academics frequently deny the existence of racism in France..$^{23}$ According to Waughray, the French have often claimed that "[their] record in matters of race and colour [is] better than the British and compared with that of the United States ... it is excellent". ${ }^{24} \mathrm{~A}$ similar belief is

18 Laplanche-Servigne 2009: 60.

19 Bonnet 2014: 1278; and Paradies 2016: 6.

20 The use of the term "Black African" is deliberate, since other peoples from the African continent, particularly North-African Arabs and Berbers, who are not "African" in a racial sense, were also subjected to French colonial rule.

21 Ndiaye 2005: 91 laments the non-recognition of racial and ethnic groups and maintains that it has contributed to the absence of studies on Black Africans as a social group in France. He opines that it is easier to find research on African Americans in France than on the history of Africans in France.

22 Roché 2007: 510; Möschel 2011: 1656. Pager 2008: 376 writes that it is impossible to assess whether crime-prevention and -enforcement strategies are formulated according to the ethnic composition of a specific area. According to Bruce-Jones 2007-2008: 439, the non-recognition of race and ethnicity makes it difficult to assess racism and to identify indirect and institutional racism in France. He is also of the opinion that the non-recognition of race inhibits all truthful and open discourse about racism in France.

23 Schneider 2008: 140.

24 Waughray 1960: 70. 
evident in accounts of its colonial history, ${ }^{25}$ where it is sometimes proclaimed that unlike other European colonial powers, the French upheld the principle of racial equality in their colonies. ${ }^{26}$ However, Cohen's study of French colonial history reveals a dominant tradition of racial inequality, particularly in relation to French colonies in Africa. ${ }^{27}$

Shortly after the Napoleonic Wars, during which the old French Colonial Empire was liquidated and French domination in Europe ended, most of France's old colonial possessions reverted to French rule by the Treaty of 20 November $1815 .{ }^{28}$ The French people and military felt the need to avenge France's wartime humiliations by expanding French influence beyond Europe, to Africa and the non-European world..$^{29}$ French colonial policy was premised upon a strategy that would export the French language and culture, thereby integrating and assimilating all colonial subjects and turning "foreigners into Frenchmen". ${ }^{30}$ French colonisers of the nineteenth century justified colonialism on the basis of a civilising mission to uplift inferior races. ${ }^{31}$

The conquest of Algeria in 1830 marked the beginning of a new French Colonial Empire in North Africa that was followed by colonial expansion in West Africa and Central Africa. ${ }^{32}$ Algeria was colonised in order to increase French influence and power in the Mediterranean, to restore French prestige and to convert Algerians to Christianity. ${ }^{33}$ However, France's assimilationist colonial strategy, which required renouncing one's culture, language and customs, was resisted in Algeria

- a predominantly Muslim nation. ${ }^{34}$ At the time of French colonial occupation, the Algerian population included indigenous Berber peoples, Arabs, Jews and a Black African minority. ${ }^{35}$ The French colonisers implemented a hierarchical system in Algeria that considered Berber and Jewish Algerians closer to the French, and easier to assimilate into French schools and to recruit as migrant labourers to mainland France. ${ }^{36}$ According to Silverstein, Arabs were described in French colonial discourse

25 It should be borne in mind that the French Empire included colonies in Africa, the Caribbean, South America, India, the Indian Ocean and Indochina.

26 Cohen 1980: ix-x.

27 Ibid.

28 Idem at 263; and Priestley 1966: 1-14.

29 Cohen 1980: 263 opines that French colonial ambitions were motivated to some extent by French traders and officials in Africa, and by geographers, explorers and missionaries.

30 Lloyd \& Waters 1991: 51.

31 Griffiths 2006: 453; and Conklin 1998: 420. According to Conklin, the upliftment of inferior races often masked the true motives of French colonialism, which were "greed, national pride ... and the quest for power" (at 421).

32 Priestley 1966: 15-29.

33 Cohen 1980: 270-276.

34 Lloyd \& Waters 1991: 52.35

Priestley 1966: 16-17.

36 Dobbin 2001-2002: 836; Duncan 1965: 264; and Silverstein 2008: 8. The Berbers were not, however, eligible to acquire French citizenship. Algerian Jews were regarded as more assimilable and allowed to acquire French citizenship from 1870. 
as lazy, hostile, violent and intellectually inferior. ${ }^{37}$ Arabs were thus regarded as unassimilable into the French nation and ineligible for French citizenship.

The establishment of the French West African Federation in 1895 with its headquarters in Dakar, Senegal, marked the commencement of French colonial expansion in West Africa. ${ }^{38}$ Cohen opines that the attitudes of French colonial officials, administrators and military officers towards Africans were influenced by the old myths and stereotypes perpetuated in French literature and popular thought, which portrayed Africans as lazy, savage, heathen and in need of European guidance. ${ }^{39}$ The establishment of a system of native justice in French West Africa maintained two parallel systems of courts. In the cities, courts were presided over by professional French magistrates. However, in native courts, French administrators, who had no legal training, were permitted to try serious crimes and to act as prosecutor, judge and investigator. This was clearly a violation of the principle of the separation of powers. ${ }^{40}$ Notwithstanding the abolition of slavery in France in 1848, African colonial subjects were subjected to forced labour in order to build railways, roads and public works. ${ }^{41}$ The policy of forced labour often included the use of the elderly and children, who could be assaulted for their refusal to work. ${ }^{42}$ Labourers were often not allocated any food rations. ${ }^{43}$ While African colonial subjects were initially regarded as ineligible to acquire French nationality, in 1912 a naturalisation law permitted a select group of West Africans to acquire French citizenship. ${ }^{44}$ Some evidence suggests that certain groups of Africans were accorded special privileges. One such group was the Fulahs of West Africa, who were accorded a privileged "White status" by nineteenth-century French colonisers in order to have racial allies in Africa. ${ }^{45}$

Many of the myths and beliefs about racism and the colonial period resonate in the belief that France is a country without racial prejudice and that, once assimilated, ${ }^{46}$ one would be treated as an equal. ${ }^{47} \mathrm{Schor},{ }^{48}$ however, disparages the French

37 Silverstein 2008: 6

38 Conklin 1998: 419. From their colonial headquarters in Dakar, the French administered the territories of Guinea, Côte d'Ivoire, French Sudan, Dahomey, Niger and Mauritania.

39 Cohen 1980: 283.

40 Conklin 1998: 433-436.

41 Griffiths 2006: 527; and Conklin 1998: 437. According to Conklin, the system of forced labour that was implemented in French West Africa violated the spirit of Republican ideals.

42 Griffiths 2006: 527.

43 See $i b i d$, who refers to the practice of some labourers buying themselves out of forced labour by the payment of fees or taxes that placed an additional financial burden on them.

44 Conklin 1998: 434-435. According to the law of 1912 (Arrêté No. 907 promulguant en Afrique Occidentale Française (AOF) le décret du 25 mai 1912 fixant les conditions de l'accéssion des indigenes de l'AOF d'acceder á la qualité de citoyen français), the African colonial subject had to be morally upright, have no criminal record, no history of bankruptcy, possess a certificate of primary school studies and possess evidence of payment of taxes.

45 Prum, Deschamps \& Barbler (eds) 2007: 5.

46 Castles 1995: 297-298; and Brubaker 1990: 387-388.

47 Stovall 1993: 55.

48 Schor 2001: 56. 
assimilationist model since it compels foreigners to renounce "their otherness" in order to become French. According to Body-Gendrot, ${ }^{49}$ while allegations of racism in France are commonly met with some degree of scepticism, this attitude is gradually changing.

\section{A brief overview of migration to France in the post- Second World-War period and the passing of an anti- racism law (the 1940s to the 1970s)}

A demand for labour in France's expanding economy prompted the arrival of waves of European and non-European colonial workers in the post-Second World War period. ${ }^{50}$ The French government preferred recruiting European workers from Italy, Spain, Portugal and Yugoslavia, since they were regarded as more assimilable ${ }^{51} \mathrm{~A}$ French law, passed in 1945, had facilitated access to French citizenship for many European immigrants. ${ }^{52}$ In 1947, Algerians, who were still subject to French colonial rule, were granted a special category of French citizenship known as "French Muslims". ${ }^{3}$ Pursuant to the granting of French citizenship to Algerians, their numbers in France increased from 20000 in 1947 to 200000 by $1955 .{ }^{54}$ Many Algerians came from rural, peasant backgrounds and were lured by the prospects of employment, regular salaries, social benefits and educational opportunities for their children. ${ }^{55}$ Despite their status as French citizens, Algerians were regarded as an alien minority since they were predominantly Muslim, practised polygamy and were largely illiterate..$^{56}$

From the mid-1960s, France began recruiting migrant labourers from its other former colonies in North and West Africa, particularly Morocco, Tunisia, Mali, Mauritania and Senegal. ${ }^{57}$ Most North-African and African migrants who arrived in France settled for unskilled jobs in French industry. ${ }^{58}$ A "threshold of tolerance" 59 principle applied in France in terms of which only certain quotas of migrants and foreigners were housed in a specific location, to avoid the creation of ghettos. From the late 1960s, the French government began constructing low-income housing

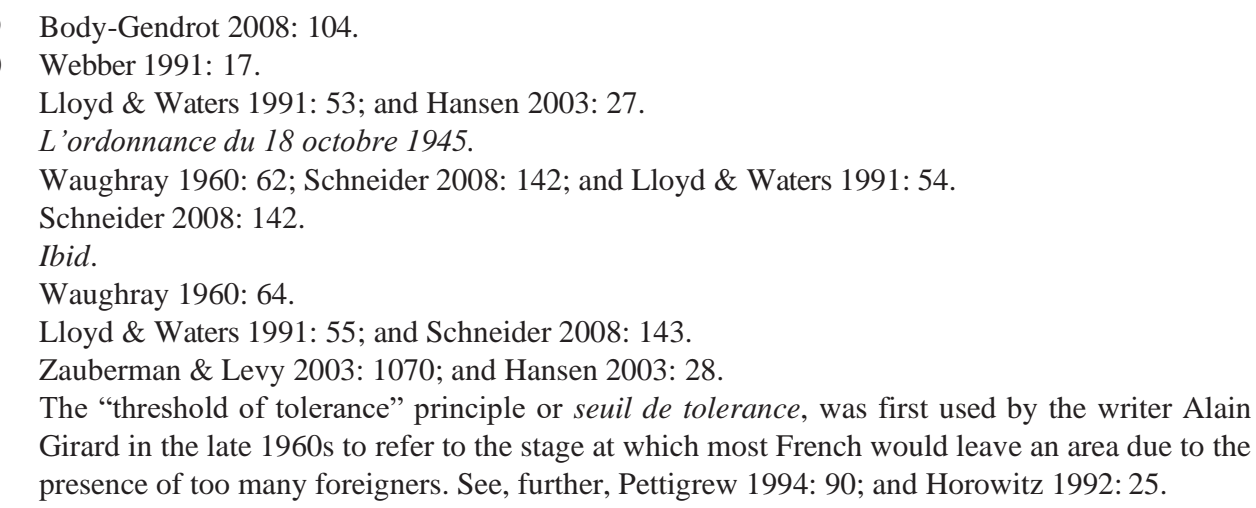


estates or cités on the peripheries of most cities. ${ }^{60}$ By the 1970 s, most North-African and African migrants were housed in peri-urban cités, firmly entrenching a system of racial and social segregation in French society. ${ }^{61}$

The oil crisis of the early 1970s had a negative impact on the French economy. Most North-African and African workers were directly affected by job losses in the textile, automotive and construction industries. ${ }^{62}$ Several writers have referred to the formation of the Front National, a right-wing political party, during this period of economic and social change. ${ }^{63}$ France was plagued by a spate of violent racist crimes. ${ }^{64}$ North-African Arabs were targeted by right-wing paramilitary groups in attacks that were reminiscent of the French-Algerian war. ${ }^{65}$ Fifty North-African Arab workers were killed and 300 sustained injuries in attacks that commenced in Marseilles and rapidly spread throughout France. ${ }^{66}$ Groups of White French men engaged in ratonnades, a colloquial French term for "rat-hunts", to find North-African Arab men to assault and murder. The identity documents and pay slips of the victims were often stolen to create the impression that the victims were illegal migrants. ${ }^{67}$ Despite many North-African Arab workers holding French citizenship, they were regarded as illegal migrants who were a burden on the state, the cause of crime and disorder, culturally inassimilable and a reminder of the French-Algerian War. ${ }^{68}$

Following France's signature and ratification of the International Convention on the Elimination of all Forms of Racial Discrimination (ICERD) on 10 November 1971, an anti-racism law was unanimously passed by the French Parliament in $1972 .{ }^{69}$ The anti-racism law of 1 July $1972^{70}$ criminalised several forms of racist conduct, which included:

Acts of provocation to discrimination, hatred or violence against a person or a group of persons by reason of their ethnicity, nationality, race or religion. Such conduct is subject to a fine and/or a period of imprisonment. ${ }^{71}$ The act provides that such conduct could be committed by speech or threats, by written or spoken words or by drawings, paintings or images that are exposed to the public and if provocation to discrimination, violence or hatred occurs. ${ }^{72}$

60 Wacquant 1993: 369; and Schneider 2008: 143.

61 Wacquant 1993: 369; and Schneider 2008: 143.

62 Zauberman \& Levy 2003: 1070-1072; and Pettigrew 1994: 83.

63 Lloyd \& Waters 1991: 57; Hansen 2003: 29; and Pettigrew 1994: 92-93.

64 Lloyd \& Waters 1991: 56; and Costa-Lascoux 1976: 182.

65 Body-Gendrot 2008: 95.

66 Gastaut 1993: 71; Silverstein 2008: 11; and Lloyd \& Waters 1991: 56.

67 Silverstein 2008: 11.

68 Lloyd \& Waters 1991: 57; and Gastaut 1993: 61.

69 Costa-Lascoux 1976: 181-182: Agostinelli 2002: 47; and Errera 1989: 49.

70 La Loi No. 72-546 du ler juillet 1972 rélative à la lutte contre le racisme and hereinafter referred to as the 1972 law.

71 Idem art 1.

72 Idem art 2. 
Defamation of a group on the basis of ethnicity, nationality, race or religion. ${ }^{73}$

The creation of a specific crime of racist, ethnic or religious injury. ${ }^{74}$

The prohibition of acts of racial, ethnic or religious discrimination by public authorities and functionaries and by private employers. ${ }^{75}$

According to Agostinelli, ${ }^{76}$ the crimes of provocation to discrimination, hatred and violence and racist injury both have common requirements, which include an act of publication that should reveal the intention of the perpetrator, and a racial element directed towards a group based on origin, ethnicity, race or religion. ${ }^{77}$ However, the crime of defamation of a group based on race, ethnicity, origin or religion requires an allegation against a group, or the imputation of facts that attack the honour of the person concerned. ${ }^{78}$ The 1972 law was successfully invoked by migrants and antiracist organisations in cases where newspapers had published advertisements for employment that was reserved only for Europeans or that had advised North Africans that they were ineligible for employment. The 1972 law has been criticised as having very limited effect since it was interpreted to apply only to overt acts of racial and ethnic discrimination. ${ }^{79}$

\section{The cités in decay, discrimination, racist crimes and the enactment of a second anti-racist law (the 1980s-1990s)}

By the early 1980s, most French cités were plagued by high levels of unemployment, overcrowded living conditions due to the high birth rate amongst North-African and African communities, a high dropout rate from schools and the greater visibility of youth on the streets. ${ }^{80}$ Wacquant ${ }^{81}$ refers to the delinquency, vandalism and moral degradation associated with the cités because of the sense of indignity experienced by most North-African and African youth who felt that they were discriminated against in their search for work, considered deviants by the criminal justice system, and subjected to constant police checks and harassment. According to French law,

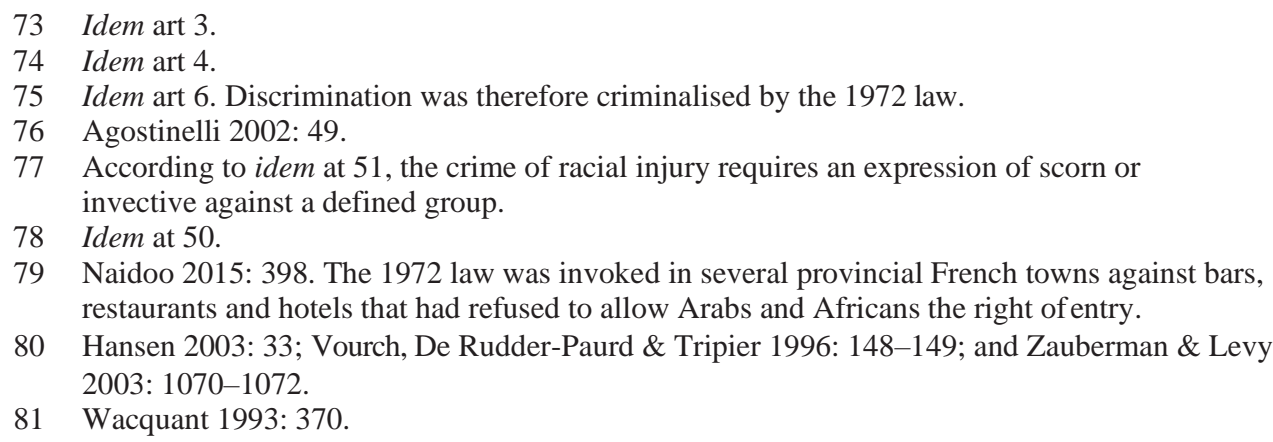

79 Naidoo 2015: 398. The 1972 law was invoked in several provincial French towns against bars, restaurants and hotels that had refused to allow Arabs and Africans the right of entry.

80 Hansen 2003: 33; Vourch, De Rudder-Paurd \& Tripier 1996: 148-149; and Zauberman \& Levy 2003: 1070-1072.

81 Wacquant 1993: 370. 
a legal obligation is imposed on any person found on French national territory to submit to an identity check by the police. ${ }^{82}$ Police officers may ask a person to provide proof of identity where reasonable grounds exist to believe that the person committed or attempted to commit an offence or may be able to provide information to the police regarding a crime ${ }^{83}$ If the person is unable to provide proof of identity, provision is made for a short period of detention in police custody in order to conduct a verification of the person's identity. ${ }^{84}$ While youth in the cités are mostly French citizens, special provisions in French law require foreigners to carry proof of identification at all times. ${ }^{85}$

In most public-sector employment vacancies in the Paris region, applicants were regarded as "undesirable" based on their residential addresses and identity photographs that usually accompanied work applications. This practice impacted most negatively on the children of migrants who resided in the cités. ${ }^{86}$

After a Socialist government led by President François Mitterand came to power in 1981, the formation of associations by foreigners was legalised, prompting the establishment of numerous ethnic-based organisations and North-African Arab youth groups. ${ }^{87}$ In a break with past practice, the French government began directing resources to ethnically-based organisations and youth groups. ${ }^{88}$ In accordance with Universalist principles, these groups were recognised as "culturally-based" organisations and not as racially or ethnically-based groupings. In areas with a high density of migrants, additional educational resources were granted in order to address inequalities in schools.$^{89}$ From the 1980s, therefore, the French government

82 Article 78-1 of the French Le Code de Procédure Pénale, hereinafter referred to as the Code of Criminal Procedure.

83 Idem art 78-2.

84 Idem art 78-3. The period of detention may not exceed four hours. In the event of a minor (a person under the age of eighteen years) being unable to provide proof of identity, the District Prosecutor must be notified of the minor's detention.

85 Foreigners are governed by a separate law, Le Code d'Entrée et du Séjour des étrangers et du Droit d'Asile (the Code governing the Entry and Residence of Foreigners and the Right to Asylum), which has been in force since 1945. According to art L611-1 of this code, a police official does not need to have grounds for suspicion before stopping a foreign person in order to perform an identity check. According to a decision of the Conseil Constitutionnel, the highest constitutional court in France, the police have to base their decision to stop a person on all surrounding circumstances (Decision No. 93-323 du Conseil Constitutionnel du 5 août 1993). In a further judgement, the Conseil Constitutionnel held that the police may not make use of discriminatory indicators on which to base their decisions to stop foreigners (Decision No. 93-323 du Conseil Constitutionnel $d u 13$ août 1993). French police should thus not use physical appearance or race and ethnicity as indicators of foreignness.

86 Vourch, De Rudder-Paurd \& Tripier 1996: 156.

87 Silverstein 2008: 11; Safran 1984: 447; and Bleich 2000: 59.

88 Lloyd 1991: 66; and Safran 1984: 447.

89 Zauberman \& Levy 2003: 1084. According to Joppke 2007: 264, these areas are referred to as zones d'éducation prioritaires (ZEPs) or priority-education areas and were identified on the basis of "socioeconomic need" but never in terms of race and ethnicity. 
gradually began to recognise the existence of different racial and ethnic groups, particularly $\mathrm{Arab}^{90}$ and Jewish groups, and their right to differ from mainstream French culture. ${ }^{91}$ However, the increased visibility of racial and ethnic groups and the rise of migrant politics led to more public debates on race and immigration and to the growing appeal of the Front National, which garnered its first electoral victory in a 1983 by-election. ${ }^{92}$ Several sources have referred to a number of murders during this period, in which North-African Arab youth were shot by 'snipers' from highrise buildings in French cités. ${ }^{93}$ According to Schneider, ${ }^{94}$ seven Arab youths were killed by sniper fire in the cités of Paris ${ }^{95}$ - a method of killing often used against Arab targets in the French-Algerian war. ${ }^{96}$ Body-Gendrot ${ }^{97}$ suggests that several of these murders were perpetrated by racist French police officials and sheriffs. The murders gave rise to numerous protests and marches for equality by North-African Arab youth and ethnic organisations, and resulted in heightened tensions with the police ${ }^{98}$ By the late 1980 s, increased conflict between youth and growing tensions in the cités were exploited by the Front National, which blamed North-African Arabs for crime and unemployment, and garnered more support in the 1988 Parliamentary elections. ${ }^{99}$

In an interview conducted with Fausto Giudice, ${ }^{100}$ he mentioned the hundreds of unsolved murders of North-African Arabs in France, which he referred to as Arabicides. ${ }^{101}$ According to Giudice:

There have not been hundreds of Africans or Indochinese murdered in France because they were Africans of Indochinese ... but hundreds of Arabs have been killed in the last twenty years ... principally because they were known as ... or looked like Arabs. ${ }^{102}$

90 It should be noted that the term Arabe in contemporary French, or the colloquial French term, Beur, are collective descriptions that could refer to North-African Arabs of Algerian, Moroccan or Tunisian origin. The terms could also apply to the indigenous Berber peoples of these countries who speak a distinct language and adhere to different cultural practices. A common thread amongst all these peoples, however, is their adherence to the Islamic faith. See, further, Safran 1984: 423.

91 Safran 1984: 447.

92 Pettigrew 1994: 92-93; Bleich 2000: 59-60; and Lloyd \& Waters 1991: 49.

93 Woodall 1993: 29; Silverstein 2008: 11; Schneider 2008: 143.

94 Schneider 2008: 143

95 Abdallah 2014: 257.

96 Woodall 1993: 29.

97 Body-Gendrot 2008: 96.

98 Silverstein 2008: 11-15; Abdallah 2014: 257; and Laplanche-Servigne 2009: 61.

99 Body-Gendrot 2008: 96; Laplanche-Servigne 2009: 60; and Schneider 2008: 144.

100 Fausto Giudice is a French journalist and author of the book Arabicides: Une Chronique Française, 1970-1991, in which he chronicled the murders of 200 Arabs in France over a twenty-year period.

101 See Woodall 1993: 21.

102 Fausto Giudice quoted in idem at 23. 
Since French criminal law did not recognise racially or ethnically-motivated crimes, ${ }^{103}$ police investigations of such crimes often overlooked the existence of a racial or ethnic motive. ${ }^{104}$ A racist, anti-Arab motive thus escaped detection. ${ }^{105}$ According to Woodall, ${ }^{106}$ until the early 1990s, French public prosecutors were disinclined to consider a racist motive as an aggravating circumstance in a case of premeditated murder. ${ }^{107}$

By the 1990s, several North-African Arabs and Africans had been killed in police custody ${ }^{108}$ or in instances of mistaken identity, while being pursued by the police. These killings led to violent confrontations between the police and youth in the cités. ${ }^{109}$ The government responded by increasing the presence of police in cités, making use of unwarranted stops and searches, and increasing the surveillance of youth. ${ }^{110}$ When charges were dismissed against the police, as was the norm in cases where the police had killed North-African Arabs and Africans, violent clashes ensued between cité youth and the police. ${ }^{111}$ Constant discriminatory checks by the police created the impression amongst North-African Arab and African youth in the cités that they were being persecuted by the police. ${ }^{112}$ By the mid-1990s, the Front National, whose policies focused on anti-immigration, had steadily attracted nine to sixteen per cent of the French vote, and had become established in mainstream politics. ${ }^{113}$ Despite some recognition by the former Minister of the Interior, JeanPierre Chevènement, that the composition of the French police did not reflect the

103 Idem at 1993: 23-24; and Costa-Lascoux 1994: 376. While the 1972 law, referred to earlier, made specific reference to race and ethnicity, it was an anti-discrimination law, which criminalised certain acts of discrimination, defamation and hate speech. This law could not be invoked in, for example, a racially-motivated murder.

104 It is the writer's submission that a lack of emphasis on race in French criminal law at the time contributed to police officials overlooking racist motives in such crimes.

105 Woodall 1993: 23-24. A similar observation has been made by Costa-Lascoux 1994: 376.

106 Woodall 1993: 23.

107 It is possible that the lack of emphasis on race in French criminal law contributed to the reluctance of French public prosecutors to consider a racist motive as an aggravating factor in cases of premeditated murder.

108 As regards the law governing police custody or la garde à vue, art 63 of the Code of Criminal Procedure provides that, where it is necessary for an inquiry, a police official may arrest and detain a person whom s/he reasonably suspects to have committed a crime, for a maximum period of twenty-four hours. Under exceptional circumstances, however, arts 706-23 and 706-29 of the Code of Criminal Procedure allow a person suspected of involvement in crimes related to terrorism or drugs to be held in police custody for a maximum period of ninety-eight hours.

109 Schneider 2008: 144-145.

110 Wacquant 1993: 377.

111 Schneider 2008: 146.

112 Zauberman \& Levy 2003: 1073.

113 Pettigrew 1994: 92-93. 
diverse reality of French society, no evidence exists to suggest that efforts to recruit more youth from migrant backgrounds into the police were successful. ${ }^{114}$

After several attacks on synagogues and violent anti-migrant crimes, the French Communist Party proposed a new anti-racist law that would criminalise hate speech and racist crimes and provide for harsher penalties for convicted perpetrators. ${ }^{115}$ Ever since a public statement made in 1987 by Jean-Marie Le Pen, the then leader of the Front National, where he stated that the Holocaust was merely a detail of history, ${ }^{116}$ the French Socialist Party had been lobbying for a new law that would prohibit "negationism" and history "revisionism". ${ }^{117}$ Despite opposition from right- wing parties, the new law, which was named after a Communist Party Member of Parliament, Jean-Claude Gayssot, was passed in $1990 .{ }^{118}$ The 1990 law ${ }^{119}$ prohibits discrimination based on ethnicity, nationality, race or religion. ${ }^{120}$ This provision of the Gayssot law merely reiterates the same provision of the 1972 law. The Gayssot law also criminalised racial defamation, Holocaust denial and the denial of crimes against humanity. According to Thirion, ${ }^{121}$ the Gayssot law aimed to combat the "verbal manifestations" of history revisionists. However, it also prohibited a variety of manifestations of such opinions, including the written form. The Gayssot law may be considered as a limitation on the right to freedom of speech and expression in France. The Gayssot law was successfully invoked in several cases that dealt with Holocaust denial in France. ${ }^{122}$ However, the problem of violent racially and ethnically-motivated crimes, or hate crimes, was still not addressed by French law.

114 Zauberman \& Levy 2003: 1087-1089.

115 Bleich 2000: 61; and Boyle 2001: 498.

116 Bleich 2000: 61; and Errera 1991: 15.

117 According to Bloch 2005-2006: 629-630, the term "negationism" was coined in 1987 by the French historian, Henry Rousso, to refer to the falsification of historical events and the discrediting of evidence, especially in relation to the Holocaust and Nazi atrocities of the Second World War. Negationists often try to pass themselves off as revisionists of history in order to acquire legitimacy. Bloch opines that in the process of revising history, they often distort authentic and established facts. Kahn 2000: 4 writes that most negationists and deniers of the Holocaust are "right-wing activists, pseudo-scholars and anti-Semites" who would like Holocaust denial to be established as a respected academic discipline.

118 Bleich 2000: 51; Body-Gendrot 2008: 97; and Geddes 2004: 339.

119 La Loi 90-615 du 13 juillet 1990, tendant á réprimer tout acte raciste, anti-Semite ou xenophobe and hereinafter referred to as the "Gayssot law".

$120 \quad$ Idem art 1.

121 Thirion 2013: 101.

122 Naidoo 2015: 412-416. The Gayssot law was successfully invoked to prosecute and convict several academics and magazine editors who questioned the numbers of Jews who had been killed during the Second World War or who argued that Jews had died from starvation and disease in German concentration camps and not in gas chambers. 


\section{Events that culminated in the passing of new laws to govern racially and ethnically-motivated crimes (the twenty-first century)}

Coinciding with the second Intifada ${ }^{123}$ in 2000, France experienced an increase in violent anti-Semitic attacks against persons and property. ${ }^{124} \mathrm{Bleich}^{125}$ refers to a "surge in anti-Jewish crimes", which included throwing stones at Jewish schoolchildren, launching Molotov cocktails at synagogues and vandalising Jewish daycarecentres. Most of these crimes were perpetrated by North-African Arab youth who regarded themselves as oppressed in France and the rest of the world, and who wanted to express solidarity with the oppressed Palestinians. ${ }^{126}$ Jews in France were specifically targeted, since they were considered to be the agents of international Imperialism and as collaborators with the anti-Muslim French state. ${ }^{127}$ Pro-Palestinian rallies in France often degenerated into attacks on Jews. ${ }^{128}$ According to Goodey, ${ }^{129}$ the increase in anti-Semitic attacks in France in the twenty-first century is illustrative of how international conflicts can have an influence on conflicts at the local level.

The perpetration of several terrorist attacks in the United States of America on 11 September 2001, have, however, also been linked to an increase in anti-Muslim crimes in France. ${ }^{130}$ The French government initially responded by introducing several measures to restore law and order. Over 1000 police officials were deployed to sensitive locations that included mosques and synagogues. ${ }^{131}$ The implication of Zaccarias Moussaoui, a French national of Moroccan origin, in the terrorist attacks of 11 September 2001, exacerbated fears in France that North-African Arab youths from the cités were susceptible to a radical form of Islam. ${ }^{132}$ According to Haubrich: "An angry, disaffected, mainly immigrant youth population lives in depressed big city suburbs which are already prone to violent crime levels. That is likely to be a breeding ground for extremism." 133

123 The first Intifada, which commenced in Dec 1987, refers to the popular Palestinian uprising against the Israeli military occupation of the Palestinian territories. See Cobban 1990: 208. The second Intifada commenced in the latter half of 2000. See, further, Usher 2003: 22.

124 Bleich 2009: 367; Mayer 2005: 144; Goodey 2008: 23; Bleich 2008: 12; Peace 2009: 108; and Safran 1984: 449.

125 Bleich 2007: 157.

126 Silverstein 2008: 19; Peace 2009: 106; Bleich 2007: 157; and Mayer 2004: 91.

127 Silverstein 2008: 19.

128 Safran 1984: 439-441. According to Safran, the attacks by North-African Arabs on Jews also provoked counter-attacks by extremist Jewish groups in France.

129 Goodey 2008: 23

130 Kassimeris 2011: 17; and Silverstein 2008: 22

131 Bleich 2008: 12.

132 Silverstein 2008: 17; and Haubrich 2003: 6.

133 Haubrich 2003: 6. 
While most youths of North-African Arab origin are French citizens, Cesari ${ }^{134}$ opines that they were never fully accepted in France based on their religion, ethnicity and poverty. ${ }^{135}$ According to Bleich, ${ }^{136}$ while Muslims were increasingly targeted after the terrorist attacks of 11 September 2001, there was also a growing tendency to associate Muslims with violence. This led to several policy and legal changes across Europe that were not overtly anti-Muslim, but were conceived of with Islamic extremism in mind. Many European states responded by introducing neutral laws, with no mention of religious beliefs or practices, but with Islamic extremism in mind. ${ }^{137}$ Danet ${ }^{138}$ refers to the issue of "insecurity" in France that influenced the passing of several laws and policies after the terrorist attacks on 11 September 2001. The French government initially passed a counter-terrorism law ${ }^{139}$ that empowered the police to stop and search vehicles in order to detect terrorist activities. ${ }^{140}$ According to Haubrich, ${ }^{141}$ the law was debated in parliament for a mere two weeks before being adopted.

In 2002, crime statistics from the French Human Rights Commission ${ }^{142}$ revealed an increase in crimes against property and persons that were motivated by race. Significantly, the statistics showed that 62 per cent of these racist crimes were antiSemitic in nature. ${ }^{143}$ In 2003 , the statistics revealed that 72 per cent of racist crimes were anti-Semitic. ${ }^{144}$ In 2002, the Minister of the Interior and the Minister of Justice began advocating stricter law-and-order measures to increase arrests and the severity

134 According to Cesari 2001: 107, since the second war in Iraq, the loyalties of North-African Arabs has been questioned in France. Cesari also suggests that the use of the term "second generation" in relation to the children of North-African Arab migrants is discriminatory since the term is never used in relation to the children of Portuguese, Italian and Polish migrants who are considered as "French". See, further, Peace 2009: 106.

135 Bruce-Jones 2007-2008: 449 also writes that, irrespective of their citizenship status, most people of colour in France are regarded as migrants. A similar view has been expressed by Oppenheimer 2008: 744 .

136 Bleich 2009: 362-363.

137 Within the context of France, Vanderlin 2008: 400 refers to Islam as the "number one" threat to the security of the country.

138 Danet 2003: 288.

139 Goris, Jobard \& Levy 2009: 45.

140 La Loi No. 2001-1063 du 15 novembre 2001 rélative à la sécurité quotidienne. Unlike art 78-2 of the Code of Criminal Procedure referred to above (see $\mathrm{n} 83$ supra), the new law gave police the right to stop and search without reasonable grounds to believe that the person concerned had committed, or had attempted to commit, a crime. The law empowered the police not to request permission from the District Prosecutor to extend periods of detention in police custody.

141 Haubrich 2003: 10.

142 Referred to in French as la Commission Consultative de Droits de l'Homme (CCDH).

143 Kassimeris 2011: 15-17; and Silverstein 2008: 22.

144 Kassimeris 2011: 17; and Silverstein 2008: 22. 
of sentences, and to heighten policing in the cités. ${ }^{145}$ The French government began monitoring the practices of certain Islamic communities, increasing the surveillance of mosques and stop-and-search practices in Muslim-dominated areas, and deporting radical Muslim clerics. ${ }^{146}$ Within this environment of increased security and the threat of extremist, fundamentalist practices of Islam, a new law was proposed by Pierre Lellouche, a Member of Parliament. ${ }^{147}$ In his proposal to the French National Assembly on 7 November 2002, Lellouche referred to a wave of unprecedented violence in France, which included attacks on schools and places of worship, the desecrations of graves, assaults and insults that affected national cohesion and violated the values of the nation, the murder of a young Frenchman of Moroccan origin and an attack on a Jewish primary school in Paris. ${ }^{148}$ He pointed to a lacuna in French criminal law that failed to consider racially and ethnically-motivated crimes against persons and property. His subsequent recommendation was that a racist motivation should be considered in the imposition of an enhanced penalty for certain offences. ${ }^{149}$ A new law was passed by the French government in 2003 with minimal parliamentary debate and a virtually unanimous vote in both houses of the French Parliament. ${ }^{150}$ The new law ${ }^{151}$ imposes harsher penalties for certain existing violent offences when they are motivated by the ethnicity, race, religion or nationality of the victim. The motive of the perpetrator serves as an aggravating factor for the imposition of a harsher penalty. ${ }^{152}$ According to the Lellouche law, ${ }^{153}$ the normal penalties incurred for serious crimes are aggravated when the crimes are committed because of the victim's actual or perceived ethnicity, nationality, race or religion. The aggravated penalties are imposed when the offence is preceded, accompanied or followed by written or spoken words, images, objects or actions of any nature, that attack the honour or reputation of the victim, or the victim's group, because of the victim's actual or supposed ethnicity, nationality, race or religion. ${ }^{154}$ Severalserious

145 Schneider 2008: 147; and Silverstein 2008: 18. According to Danet 2003: 276, the issue of insecurity became more prominent after the 2002 presidential elections.

146 Bleich 2009: 368-369.

147 Bleich 2007: 158.

148 Lellouche 2002: passim.

149 Ibid.

150 Bleich 2008: 12; Peace 2009: 107; and Bleich 2009: 368-369.

151 La Loi No. 2003-88 du 3 février 2003 and hereinafter referred to as the "Lellouche law".

152 Body-Gendrot 2008: 98. There are many similarities between the approach adopted in the Lellouche law in France and the British Crime and Disorder Act of 1998, which created aggravated penalties for several pre-existing crimes.

153 Article 1 of the Lellouche law.

154 This general provision relating to aggravated penalties for serious crimes/felonies and misdemeanours can be found in art 132-76 of the French Penal Code. According to the wording of art 132-76, the racist or discriminatory motive for the offence can consist of various forms of human behaviour and can be present before, during or after commission of the offence. 
crimes are subject to the provisions of the Lellouche law and include ${ }^{155}$ murder, ${ }^{156}$ torture ${ }^{157}$ and damage to property. ${ }^{158}$

The enactment of a further new law in $2004^{159}$ widened the scope of serious offences that are susceptible to aggravated penalties when racist motives are present and include, inter alia, the crimes of threats to commit a serious offence against the person ${ }^{160}$ and extortion. ${ }^{161}$ Bleich lauds the highly symbolic nature of the Lellouche law since it affirms the French Republic's commitment to equality and serves to reassure vulnerable groups. ${ }^{162}$

\section{Further laws, government policies and initiatives recognising race and ethnicity}

Despite the adoption of a "colour-blind" model, some evidence suggests that the French state presently acknowledges the existence of racial and ethnic divisions in their society. As has been discussed above, since the 1980s, the French government has recognised the existence of ethnically-based organisations and youth groups who received funding in the name of culture. The French government also recognised priority education area that received additional funding and resources for schools on the basis of socio-economic need. In the 1990s, efforts were made to recruit more youths with immigrant origins into the police force. Irrespective of the use of the terms "culture", "socio-economic need" or "immigrant origins", these are in effect

155 The relevant articles of the French Penal Code that contain the serious crimes will be cited, as will the articles of the French Penal Code that contain the penalty amendments following the enactment of the Lellouche law.

156 The crime of murder is defined in art 221-1 of the French Penal Code as the voluntary causing of death of another person and is punishable by a thirty-year period of imprisonment. The crime of murder is punishable by life imprisonment when it is committed because of the victim's actual or supposed ethnicity, nationality, race or religion. See art 221-4 of the French Penal Code.

157 The crime of subjecting a person to torture or inhumane acts is normally punishable by a fifteenyear period of imprisonment. The penalty for torture is increased to a twenty-year period of imprisonment when it is committed because of the victim's actual or supposed ethnicity, nationality, race or religion. See art 222-3 of the French Penal Code.

158 According to art 322-2 of the French Penal Code, the offence of destroying, defacing or damaging property belonging to another person is punishable by a two-year period of imprisonment and a fine of $€ 30000$. However, the offence of damage to property is punishable by a three-year period of imprisonment and a fine of $€ 45000$ when the offence is committed because of the ethnicity, nationality, race or religion of the owner or the user of the property. See art 322-6 of the French Penal Code.

159 La Loi 2004-204 du 9 mars 2004 portant sur l'adaptation de la justice aux évolutions de la criminalité, which is also referred to as the "Perben II" law.

160 See arts 221-17 to 221-18-1 of the French Penal Code.

161 See arts 312-1 to 312-2 of the French Penal Code.

162 Bleich 2007: 158-159. 
replacement or "proxy" terms ${ }^{163}$ for race and ethnicity. The further use of "proxy terms" is also evident in the French Labour Code, which recognises the existence of direct and indirect discrimination on the basis of race and ethnicity, but also includes alternative grounds for discrimination on the basis of "origin", "physical appearance" and "family name". ${ }^{164}$

Several other French government initiatives indirectly recognise racial and ethnic differences, namely ${ }^{165}$

- the introduction of special courses by the French government since 2000 to prepare citizens from underprivileged areas who wish to enter the public service;

- the introduction of quotas in 2001 by the Institute d'Etudes Politiques (IEP) ${ }^{166}$ to benefit students from priority educations areas; ${ }^{167}$ and

- the increased recognition of the "children of migrants" 168 who are never referred to in terms of their race or ethnicity.

\section{Conclusion}

The enactment of several French laws that explicitly recognise race and ethnicity may be considered as a departure from the Universalist ideals that inspired the principle that race and ethnicity are not recognised and the adoption of a "colour-blind" model. While the 1972 law, which was passed as a result of France's international human rights obligations, outlawed discrimination, it has had very limited effect due to it being interpreted to apply only to overt acts of racial discrimination. ${ }^{169}$ The 1990 Gayssot law, which was enacted after a surge in anti-Semitic attacks and incidences of anti-Semitic speech, prohibits discrimination on several more grounds and criminalises the defamation of a group of people, as well as Holocaust denial. This law has been successfully invoked in the prosecution of history revisionists and Holocaust negationists. In 2003 and 2004, laws akin to hate-crime laws were passed with Islamic extremism in mind and within an environment of heightened security.

163 Bruce-Jones 2007-2008: 432; and Joppke 2007: 263.

164 Article L1132-1 of the French Labour Code or le Code du Travail.

165 Joppke 2007: 264-265. An attempt by Nicolas Sarkozy, the former President, to introduce a national policy of affirmative action and racial quotas, was vehemently opposed in France.

166 IEP or the Institute of Political Studies is a prestigious grande école or school of higher learning in France.

167 According to Oppenheimer 2008: 744, the extent of residential segregation is sufficient in France for the IEP quota system based on economically-disadvantaged areas to serve as a proxy for race and ethnicity.

168 This is a close translation of the French expression, les jeunes issues de l'immigration.

169 The 1972 law did not, for example, address the more insidious forms of discrimination, such as institutional discrimination. 
These laws subject specific crimes motivated by race and ethnicity to enhanced penalties. Several government policies and initiatives tacitly recognise race and ethnicity. These policies have been used, inter alia, to fund ethnically-based groups, to award additional educational resources to disadvantaged areas and to prepare underprivileged students for the public service.

In 2007, following a recommendation from the Commission Nationale pour l'Informatique et les Libertés (CNIL) ${ }^{170}$ the French National Assembly attempted to pass a law that would have permitted the collection of racial and ethnic data of French citizens in order to measure the levels of discrimination and integration in France. ${ }^{171}$ More than sixty members of the French Socialist Party opposed the law on the basis that it was unconstitutional and requested a review of the law by the Conseil Constitutionnel. ${ }^{172}$ The Conseil Constitutionnel ${ }^{173}$ found that the law would have allowed for studies to be conducted on the ethnicity and race of citizens to determine the levels of discrimination and integration in France. While the Conseil Constitutionnel accepted that such studies could be based on objective facts, which could include a person's surname, geographical origin and their nationality prior to obtaining French nationality, it could not explicitly be based on race or ethnicity. If such studies revealed a person's race and ethnicity, it would conflict with article 1 of the French Constitution. ${ }^{174}$ The Conseil Constitutionnel, in effect, strictly interpreted Article 1 of the French Constitution and did not allow for any derogation from the principle of equality. The proposed law was therefore declared to be unconstitutional by that Court. ${ }^{175}$

Faced with the increased recruitment of young French nationals by the terrorist group Islamic State, ${ }^{176}$ the French government passed a counter-terrorism law

170 CNIL may be translated into English as the National Commission for Information Technology and Civil Liberties, and is the French agency responsible for the maintenance of privacy.

171 Oppenheimer 2008: 746.

172 Ibid.

173 Décision No. 2007-557 du 15 novembre 2007 available at https://www.Conseil-constitutionnel.fr/ decision/2007/2007557DC.html (accessed 1 Jun 2019).

174 Refer to nn 9 and 16 supra, where reference has been made to art 1 of the French Constitution of 1958. This article of the French Constitution, which provides for equality before the law without distinction as to race, ethnicity or religion, has been traced to the principles enunciated in the Declaration of the Rights of Man and of the Citizen of 1789, which provides that all men are born equal. The explicit recognition of race and ethnicity is regarded as anathema to the Universalist ideals of the French Revolution and the idea of a united, undivided nation.

175 The judgement of the Conseil Constituionnel in hoc casu could be criticised as being rather brief, particularly if compared to the comprehensive judgements of courts in common-law jurisdictions. In deciding that the law concerned was unconstitutional, the Conseil Constitutionnel simply said that such law was in conflict with art 1 of the French Constitution. It, however, should be noted that the brevity of French law reports has been referred to in several sources. See, further, Elliot 2001: 228; Steiner 1995-1996: 51.

176 Popularly referred to as the "Islamic State in Syria" (ISIS) or the "Islamic State in Iraq and the Levant" (ISIL). 
in $2014^{177}$ that prohibits French citizens from leaving France to receive terrorist training in a foreign country and from defending or inciting acts of terrorism. The perpetration by young French citizens of several terrorist attacks in France between 2012 and 2017 confirms the fears expressed by French politicians and writers of angry, marginalised Arab and African youths, most of whom are the children of migrants and are susceptible to a radical form of Islam and recruitment by terrorist groups. ${ }^{178}$

In 2018, the French National Assembly unanimously voted to remove the word "race" from the French Constitution and to replace it with the word "gender", since race was regarded as an unfounded concept with no scientific value. ${ }^{179}$

In its reluctance to acknowledge the existence of race and ethnicity, the French state denies the social realities of its many citizens of colour. ${ }^{180}$ According to Oppenheimer, ${ }^{181}$ the French practice of "colour-blindness" masks the colourconsciousness of French society where discrimination and inequality are closely linked to race and ethnicity. ${ }^{182} \mathrm{Barou}^{183}$ also opines that there is a crisis in France with the "colour-blind" model since many of the children of migrants are socially and economically excluded. The "colour-blind" model has also been the subject of negative criticism since it presupposes equal opportunities across all races and because it does not end racist practices in society. ${ }^{184}$

Several writers have therefore advocated for the greater recognition of race and ethnicity in France, and for the collection of racial and ethnic data to enable the state to determine how race and ethnicity affects the lives of its citizens. ${ }^{185}$ According to Zauberman and Levy, ${ }^{186}$ there is a need to adapt sacrosanct Republican principles by highlighting characteristics that the French state wants to ignore and render insignificant.

A greater recognition of race and ethnicity in France could facilitate the collection of data that would shed light on the extent of discrimination and racial violence in France. It would also enable comparative studies to be conducted on race and ethnicity in France, which could inform future government policies and laws. Bruce-Jones ${ }^{187}$ compares the non-recognition of race and ethnicity in France

177 La Loi No. 2014-1353 du 13 novembre 2014 renforçant les dispositions relatives à la lutte contre le terrorisme.

178 Joshi 2015: passim.

179 Mohdin 2018: passim; and Fassassi 2018: passim. Since this constitutional amendment, art 1 of the French Constitution of 4 Oct 1958 now refers to the equality of all citizens before the law, without distinction as to "origin, gender or religion".

180 Bruce-Jones 2007-2008: 469.

181 Oppenheimer 2008: 742.

182 A similar view has been expressed by Schneider 2008: 152 .

183 Barou 2014: 644.

184 Modica 2015: 398; and Paradies 2016: 6.

185 Zauberman \& Levy 2003: 1091; Bruce-Jones 2007-2008: 470; and Oppenheimer 2008: 747.

186 Zauberman \& Levy 2003: 1091.

187 Bruce-Jones 2007-2008: 470. 
to its explicit recognition in the United States of America where such recognition enabled the expression "Black is beautiful" and the coining of the hybrid category "African American", which, while denoting difference, still claims belonging to a multicultural American identity.

The Universalist ideals were first articulated during the period of the French Revolution in the late eighteenth century. These ideals crystallised into several principles during the Republican period of the nineteenth century, one of which was the principle that racial and ethnic groups are not recognised in France. Adherence to this principle was undoubtedly significant during the nineteenth century when the French nation state was in its infancy and the emphasis was on a common French citizenship that recognised no hierarchy or divisions. It led to the adoption of a "colour-blind" model of assimilation that was meant to counter racism and racial discrimination. It is the writer's submission that allegiance to this principle, which espouses the non-recognition of race, ethnicity and "colour-blindness", appears somewhat out of sync in the twenty-first century, particularly in a multicultural state that needs to be more inclusive, and to fully recognise and embrace its diverse population.

\section{Bibliography}

abdallah, Mogniss (2014) “La marche pour l'égalité et contre le racisme n'est pas assez entrée dans l'histoire" Vacarme 2(67): 256-267

Agostinelli, Xavier (2002) "Diffamation, injure et provocation à la discrimination raciale" Legicom 3(28): 47-60

Barou, Jacques (2014) "Integration of immigrants in France: A historical perspective" Identities 21(6) : 642-657

Bird, Karen (2000) "Racist speech or free speech? A comparison of the law in France and the United States" Comparative Politics 32: 399-418

Bleich, Erik (2000) "Anti-racism without races: Politics and policy in a 'colour-blind' state" French Politics, Culture and Society 18(3): 48-74

Bleich, Erik (2007) "Hate-crime policy in Western Europe: Responding to racist violence in Britain, Germany and France" American Behavioral Scientist 51(2): 149-165

Bleich, Erich (2008) "Responding to racist violence in Europe and the United States" in J Goodey \& K Aromaa (eds) Hate Crime: Papers from the 2006 and 2007 Stockholm Criminology Symposium (Helsinki): 9-15

Bleich, Erik (2009) 'State responses to 'Muslim' violence: A comparison of six West European countries" J of Ethnic and Migration Studies 35(3): 361-379

Bleich, Erik (2011) "The rise of hate speech and hate-crime laws in liberal democracies" $J$ of Ethnic and Migration Studies 37(6): 917-934

Bloch, Pascale (2005-2006) "Response to Professor Fronzas: The punishment of negationism" Vermont LR 30: 627-643 


\section{RACE, ETHNICITY, DISCRIMINATION AND VIOLENCE IN “COLOUR-BLIND” FRANCE}

Body-Gendrot, Sophie (2008) "France" in J Winterdyk \& G Antonopoulos (eds) Racist Victimization: International Reflections and Perspectives (Abingdon): 89-111

Bonnet, François (2014) "How to perform racism? Colour-blind speech, norms and race-conscious policies among French security personnel” JofEthnic and Migration Studies 40(8): 1275-1294

Boyle, Kevin (2001) "Hate speech - the United States versus the rest of the world" Maine LR 53(2): 488-502

Bruce-Jones, Eddie (2007-2008) "Race, space and the nation-state: Racial recognition and the prospects for substantive equality under anti-discrimination law in France and Germany" Columbia Human Rights LR 39: 423-470

Brubaker, William Rogers (1990) "Immigration, citizenship and the nation-state in France and Germany: A comparative, historical analysis” International Sociology 5(4): 375-407

Calamur, K (2017) "France's latest terrorist attack" 20 Apr 2017 Atlantic available at https://www. theatlantic.com/international/archive/2017/04/france-attack/523812 (accessed 6 Oct 2018)

Castles, Stephen (1995) "How nation-states respond to immigration and ethnic diversity" J of Ethnic and Migration Studies 21(3): 293-308

Cesari, Jocelyne (2001) “Islam de l'exterieur, musulmans de l'intérieur: deux visions après le 11 septembre 2001" Culture et Conflits 44: 97-115

Cobban, Helena (1990) "The PLO and the Intifada" Middle East J 44(2): 207-233

Cohen, William B (1980) The French Encounter with Africans: White Response to Blacks, 15301880 (Bloomington)

Conklin, Alice (1998) "Colonialism and human rights, a contradiction in terms? The case of France West Africa, 1895-1914” American Historical Review 103(2): 419-442

Costa, Jean-Paul (1992) “La perception par le Conseil d'État du concept de race” Mots 33: 339-342

Costa-Lascoux, Jacqueline (1976) "La loi du 1er juillet 1972 et la protection pénale des immigrés contre la discrimination raciale" Droit Social 5: 181-187

Costa-Lascoux, Jacqueline (1994) "French legislation against racism and discrimination" J of Ethnic and Migration Studies 20(3): 371-379

Danet, Jean (2003) "Le droit pénal et la procédure pénale sous le paradigme de l'insécurité" Archives de politique criminelle 25: 276-288

Décision No 2007-557 du 15 novembre 2007 available at https://www.conseil-constitutionnel.fr/ decision/2007/2007557DC.html (accessed 1 Jun 2019)

Diémert, Stéphane (2005) “Le droit de l'outre-mer” Pouvoirs 113: 101-112

Dobbin, Frank (2001-2002) "Do the social sciences shape corporate anti-discrimination practice? The United States and France" Comparative Labour Law and Policy J 23: 829-864

Dubois, Laurent (2000) “La République Metisée: Citizenship, colonialism and the borders of French history" Cultural Studies 14(1): 15-34

Duncan, Patrick (1965) "Is apartheid an insoluble problem?” Race and Class 6: 263-266

Elliot, Catherine (2001) French Criminal Law (Cullompton)

Errera, Roger (1989) "France: Recent developments in anti-Nazi and anti-discrimination legislation" Patterns of Prejudice 23(1): 47-49 
Errera, Roger (1991) "Balancing legitimate rights: Freedom of the press and other rights in French law" Communications Lawyer 9: 13-15

Fassassi, Idris (2018) "Removing 'race' and adding 'gender' to the French Constitution: On constitutional redundancy and symbols" 24 Aug 2018 ConstitutionNet available at constituionnet.org/new/removing-race-and-adding-gender-french-constituional-redundancyand-symbols (accessed 1 Apr 2019)

Gastaut, Yvan (1993) “La Flambée Raciste de 1973 en France” Revue européenne de migrations internationales 9(2): 61-75

Geddes, Andrew (2004) "Britain, France and EU anti-discrimination policy: The emergence of an EU policy paradigm” West European Politics 27(2): 334-353

Goodey, Jo (2008) "Racist crime in the European Union: Historical legacies, knowledge gaps and policy development" in J Goodey \& K Aromaa (eds) Hate Crime: Papers from the 2006 and 2007 Stockholm Criminology Symposium (Helsinki): 16-28

Goris, Indira, Fabien Jobard \& René Levy (2009) Profiling Minorities: A Study of Stop and Search in Paris (New York)

Griffiths, Claire (2006) "Colonial subjects: Race and gender in French West Africa” International $J$ of Sociology and Social Policy 26(12): 449-594

Hansen, Randall (2003) "Migration to Europe since 1945: Its history and its lessons" Political Quarterly 74(1): 25-38

Haubrich, Dirk (2003) "September 11, anti-terror laws and civil liberties: Britain, France and Germany compared" Government and Opposition 38(1): 3-28

Horowitz, Donald L (1992) "Immigration and group relations in France and America" Bulletin of the American Academy of Arts and Sciences 45(4): 9-30

Joppke, Christian (2007) "Transformation of immigrant integration: Civic integration and antidiscrimination in the Netherlands, France and Germany" World Politics 59(2): 243-273

Joshi, Shashank (2015) "Charlie Hebdo attack: A French intelligence failure?" 10 Jan 2015 BBC News Online available at http://www.bbc.com/news/world-europe-30760656 (accessed 13 Jun 2018)

Kahn, Robert A (2000) "Rebuttal v. unmasking: Legal strategy in $R v$ Rundel" Patterns of Prejudice 34(3): 3-15

Kassimeris, Christos (2011) "Black, blanc and beur: French football's 'Foreign Legion'” J of Intercultural Studies 32(1): 15-29

La Déclaration des Droits de l'Homme et du Citoyen de 1789 available at http://www.legifrance. gouv.fr/Droit-français-Constitution/Déclaration-des-droits-de-l'Homme (accessed 1 Apr 2019)

Laplanche-Servigne, Soline (2009) 'La lutte contre le racisme des 'minorisés' en France et en Allemagne depuis les anneés 1980's” Hommes et Migrations 1277: 56-66

Lellouche, Pierre (2002) "Proposition de la loi visant á aggraver les peines punissant les infractions á caractère raciste et á renforcer l'efficacité de la procédure pénale" available at $h t t p: / / w w w$. assemblee-nationale.fr/12/pdf/propositions/pion0350.pdf (accessed 17 May 2018)

Lloyd, Cathie (1991) "Concepts, models and anti-racist strategies in Britain and France" J of Ethnic and Migration Studies 18(1): 63-73 


\section{RACE, ETHNICITY, DISCRIMINATION AND VIOLENCE IN “COLOUR-BLIND” FRANCE}

Lloyd, Cathie \& Hazel Waters (1991) "France: One culture, one people?" Race and Class 32(3): $49-64$

Mayer, Nonna (2004) “Nouvelle judéophobie ou vieil anti-Sémitisme?" Raisons Politiques 16: 91-99

Mayer, Nonna (2005) "Les opinions anti-Sémites en France après la seconde Intifada" La Revue Internationale et Stratégique 58: 143-150

Modica, Marianne (2015) 'Unpacking the 'colour-blind' approach: Accusations of racism at a friendly, mixed-race school" Race, Ethnicity and Education 18: 396-418

Mohdin, Aamna (2018) "France replaces the word 'race' with 'sex' in its Constitution" 28 June 2018 Quartz available at https://qzcom/1316951/french-mps-removed-the-word-race-fromthe-country's-Constitution (accessed 1 Apr 2019)

Möschel, Mathias (2011) "Race in mainland European legal analysis: Towards a European critical race theory" Ethnic and Racial Studies 34(10): 1648-1664

Naidoo, Kamban (2015) A Comparative and Historical Legal Study of Hate Crimes Motivated by Race and Ethnicity (LLD, University of South Africa)

Ndiaye, Pap (2005) "Pour une histoire des populations noires en France: Préalables théoriques" Le Mouvement Social 213: 91-108

Oppenheimer, David Benjamin (2008) "Why France needs to collect data on racial identity ... in a French way" Hastings International and Comparative LJ 31: 735-752

Pager, Devah (2008) "The Republican ideal? National minorities and the criminal justice system in contemporary France" Punishment and Society 10(4): 375-400

Paradies, Yin (2016) “Whither anti-racism?” Ethnic and Racial Studies 39(1): 1-15

Peace, Timothy (2009) "Un antisémitisme nouveau? The debate about a new anti-Semitism in France" Patterns of Prejudice 43(2): 103-121

Pettigrew, Thomas F (1994) "Reactions toward the new minorities of Western Europe" Annual Review of Sociology 24: 77-103

Priestley, Herbert Ingram (1966) France Overseas: A Study of Modern Imperialism (New York)

Prum, Michel, Bénédicte Deschamps \& Marie-Claude Barbier (eds) (2007) Racial, Ethnic and Homophobic Violence: Killing in the Name of Otherness (Abingdon)

Roché, Sébastian (2007) "Criminal justice policy in France: Illusions of severity" Crime and Punishment 36(1): 471-550

Safran, William (1984) “The French left and ethnic pluralism” Ethnic and Racial Studies 7(4): $447-461$

Schneider, Cathy Lisa (2008) "Police power and race riots in Paris" Politics and Society 36(1): $133-155$

Schor, Naomi (2001) "The crisis of French universalism" Yale French Studies 100: 43-64

Silverstein, Paul A (2008) "The context of anti-Semitism and Islamophobia in France" Patterns of Prejudice 42(1): 1-26

Steiner, Eva (1995-1996) “The application of the European Convention on Human Rights by French courts" Kings College LJ 6: 49-61

Stovall, Tyler (1993) "Colour-blind France? Colonial workers during the First World War" Race and Class 35(2): 35-55 
Thirion, Nicolas (2013) “Discours de haine et police du langage (à propos d'un ouvrage de Judith Butler, 'Le Pouvoir des Mots'): Politique du performatif' Revue de philosophie politique de l'ULG 3: 100-116

Tilly, Charles (1995) "The emergence of citizenship in France and elsewhere" Citizenship, Identity and Social History 40: 223-236

Usher, Graham (2003) "Facing defeat: The Intifada two years on" J of Palestine Studies 32(2): $21-40$

Vanderlin, Pierre (2008) "Gérard Noiriel, racisme: La responsibilité des élites: Entretien mené par Bertrand Richard" Questions de Communication 14: 398-401

Vourch, François, Véronique de Rudder-Paurd \& Maryse Tripier (1996) "Racisme et discriminations dans le travail: Une réalité occulté” L'Homme et la Société 121-122: 145-160

Wacquant, Löic JD (1993) "Urban outcasts: Stigma and division in the Black American ghetto and the French urban periphery" International J of Urban and Regional Research: 366-383

Waughray, Vernon (1960) “The French racial scene: North African migrants in France" Race and Class 2(1): 60-70

Webber, Frances (1991) “From ethnocentrism to Euro-racism" Race and Class 32(3): 11-17 Weil,

Patrick \& John Crowley (1994) "Integration in theory and practice: A comparison of France and Britain" West European Politics 17(2): 110-126

Woodall, Chris (1993) “Arabicide in France: An interview with Fausto Giudice” Race and Class 35(2): $21-33$

Zauberman, Renée \& René Levy (2003) "Police, minorities and the French left republican ideal" Criminology 41(4): 1065-1100

\section{Case law}

Conseil Constitutionnel, Décision No. 2007-557DC du 15 novembre 2007 (Decision No 2007557DC of the Conseil Constitutionnel of 15 Nov 2007)

Conseil Constitutionnel, Decision No. 93-323 du 5 août 1993 (Decision No 93-923 of the Conseil Constutionnel of 5 Aug 1993)

Conseil Constitutionnel, Decision No. 93-323 du 13 août 1993 (Decision No 93-323 of the Conseil Constitutionnel of 13 Aug 1993)

\section{Legislation}

\section{France}

Arrêté No. 907 promulguant en Afrique Occidentale Française (AOF) le décret du 25 mai 1912 fixant les conditions de l'accéssion des indigenes de l'AOF d'acceder á la qualité de citoyen français)

French Constitution of 4 October 1958

La loi Informatique et Libertés no. 78-17 du 6 janvier 1978 (The French Data Protection and Individual Freedom Law No 78-17 of 6 Jan 1978) 


\section{RACE, ETHNICITY, DISCRIMINATION AND VIOLENCE IN “COLOUR-BLIND” FRANCE}

La Loi No. 72-546 du ler juillet 1972 rélative à la lutte contre le racisme (The Anti-Racism Law No $72-546$ of 1 Jul 1972)

La Loi No. 90-615 du 13 juillet 1990, tendant á réprimer tout acte raciste, anti-Semite ou xenophobe (The Anti-Semitism and Anti-Xenophobia Law No 90-615 of 13 Jul 1990)

La Loi No. 2001-1063 du 15 novembre 2001 rélative à la sécurité quotidienne (Law No 20011063 of 15 Nov 2001 relating to daily security)

La Loi No. 2003-88 du 3 février 2003 visant à aggraver les peines punissant les infractions à caractère raciste, antisémite ou xénophobe (Law No 2003-88 of 3 Feb 2003 to increase penalties for racist, anti-Semitic and xenophobic crimes)

La Loi No. 2004-204 du 9 mars 2004 portant sur l'adaptation de la justice aux évolutions de la criminalité (Law No 2004-204 of 9 Mar 2004 on the adaptation of justice to evolutions in crime)

La Loi No. 2014-1353 du 13 novembre 2014 renforçant les dispositions relatives à la lutte contre le terrorisme (Law No 2014-1353 of 13 Nov 2014 reinforcing provisions relating to the fight against terrorism)

Le Code d'Entrée et du Séjour des Étrangers et du Droit d'Asile, 1945 (The Code Governing the Entry and Residence of Foreigners and the Right to Asylum of 1945)

Le Code de Procédure Pénale, 1958 (The French Code of Criminal Procedure, 1958)

Le Code du Travail, 1973 (The French Labour Code, 1973)

Le Code Pénal, 1994 (The French Penal Code, 1994)

L'ordonnance du 18 octobre 1945 (Ordinance of 18 Oct 1945) 